\title{
Polymorphism of CAST and GDF-8 genes and association with physical-chemical parameters of sheep meat
}

\author{
C. Esteves ${ }^{1}$, K.G. do Livramento ${ }^{2}$, L.V. Paiva ${ }^{2}$, A.P. Peconick ${ }^{1}$, \\ I.F.F. Garcia ${ }^{3}$, C.A.P. Garbossa ${ }^{4}$, T.B. Cardoso ${ }^{5}$ and P.B. Faria ${ }^{1}$ \\ ${ }^{1}$ Departamento de Medicina Veterinária, Universidade Federal de Lavras, \\ Lavras, MG, Brasil \\ ${ }^{2}$ Departamento de Química, Universidade Federal de Lavras, Lavras, MG, Brasil \\ ${ }^{3}$ Departamento de Ciências Animais, Universidade Federal de Lavras, Lavras, \\ MG, Brasil \\ ${ }^{4}$ Departamento de Produção e Nutrição Animal, Faculdade de Medicina \\ Veterinária e Zootecnia, Universidade de São Paulo, Pirassununga, SP, Brasil \\ ${ }^{5}$ Laboratório Central de Biologia Molecular, Universidade Federal de Lavras, \\ Lavras, MG, Brasil
}

Corresponding author: C. Esteves

E-mail: claudianaesteves@yahoo.com.br

Genet. Mol. Res. 19 (3): gmr18325

Received April 14, 2019

Accepted August 31, 2020

Published September 30, 2020

DOI http://dx.doi.org/10.4238/gmr18325

\begin{abstract}
In Brazil, most sheep are of the Santa Inês breed, which shows rusticity in breeding and grazing systems, being able to offer better adaptation characteristics for animals with meat production ability, such as the Texel and Dorper sheep. They can also improve meat production in animals that have better characteristics for milk production, such as Lacaune and East Friesian breeds. We investigated the polymorphisms of calpastatin (CAST) and myostatin (GDF8) genes and their association with meat quality parameters of 84 lambs, including: 14 purebred Santa Inês and 70 crossbred animals of five genetic groups: 16 animals ( $1 / 2$ Santa Inês $x 1 / 2$ Black Dorper); 12 animals ( $1 / 2$ Santa Inês X $1 / 2$ White Dorper); 19 animals ( $(1 / 2$ Santa Inês x $1 / 2$ Texel); 14 animals ( $1 / 2$ Santa Inês x $1 / 2$ Lacaune); and 9 animals ( $1 / 2$ Santa Inês x $1 / 2$ East Friesian). To evaluate the polymorphism of the genes we used PCR and Simple Chain Conformation Polymorphism (SSCP) with DNA sequencing to determine where base exchange occurred in the gene sequences. The PCR-SSCP technique detected four bands of the CAST gene and three of the GDF-8 gene. In meat quality of sheep there was
\end{abstract}


only one different breed group by Shear force with less value than Santa Ines breed group. The CAST gene had four genotypes with two single nucleotide polymorphisms (SNPs) (c.679A $>$ G; c.383A> G), which resulted in the exchange of glutamic acid by glycine and threonine by alanine, which impacted $\mathrm{pH}$ values. Reduced $\mathrm{pH}$ values for $\mathrm{BB}$ and $\mathrm{AB}$ genotypes, and increased $\mathrm{pH}$ value in the AA genotype were found. Three genotypes of the DGF-8 gene with three SNPs were identified with changes of A-T, A-G, and T-G, influencing color hue angle $\left(h^{*}\right)$. After 10 days post mortem, there was an increase in hue angle the highest values were found for genotypes DF and DE. The polymorphisms of the CAST gene and in the promoter region of the GDF-8 gene influence meat color and final $\mathrm{pH}$, affecting meat quality in various of the sheep breed groups.

Key words: Meat tenderness; Calpastatin; Myostatin; PCR-SSCP; Meat quality

\section{INTRODUCTION}

Brazilian sheep farming has a significant social and economic impacts, especially in Northeast of Brazil, contributing to the provision of foods of high biological value, increased income and social inclusion (Lira et al., 2017). The emphasis has been on obtaining animals for meat production; therefore genetic studies with some breeds of sheep in Brazil are being carried out to search for animals for increased production of meat with desirable quality (Ávila et al., 2013).

In Brazil, the main breed of sheep is Santa Inês. These are animals widely used for crossing with other breeds due to rusticity and adaptability characteristics to the breeding and grazing systems in the different regions (Corradello, 1988). The Texel and Dorper breeds are reared for meat production with good carcass characteristics and have high potential for use in crossbreeding, due to their precocity and muscle development and meat quality (Amaral et al., 2011). On the other hand, Lacaune and East Friesian breeds having better characteristics of milk production and their crossing with Santa Inês breed would provide a better option for meat production, due to the improvement of conformation, precocity and meat quality (Kuchtik et al., 2008; Oliveira et al., 2011).

Currently, consumers are more demanding about the safety, flavor, uniformity, nutritional value and appearance of the meat (Adeyemi and Sazili, 2014). Despite of this, tenderness is still considered the organoleptic characteristic of greatest influence and impact on the acceptance of the meat by consumers (Alvez and Mancio, 2007). However, the selection conducted to acquire more profitable animals for the desirable characteristics is still carried out based on phenotypic records and not on genetic possibilities (Allais et al., 2011). Therefore, molecular studies associated with the characteristics of the meat may provide valuable information about its quality, being marker-assisted selection an option that should be improved (Allais et al., 2011).

Some studies with molecular markers of the single nucleotide polymorphism (SNP) related to calpastatin (CAST) and myostatin (GDF-8) genes demonstrate the relationship of SNPs with growth and meat quality (Guimarães et al., 2007; Allais et al., 2011; Azari et al., 2012; Aali et al., 2014; Trukhachev et al., 2015) and Calpastatin is the main inhibitor of the action of calpains, proteins responsible for the degradation of myofibrillar proteins at post 
mortem. Studies have shown a close relationship between this inhibitor and meat tenderness; low calpastatin activity is directly associated with increased post mortem tenderness (Alvez and Mancio, 2007; Calvo et al., 2014). Changes in the physicochemical properties (including hydrophobicity, amphiphilicity and net charge) of the CAST protein may influence its structure and impact on the activity of $\mathrm{Ca}^{2+}$ channels; therefore, they can regulate calpain activity, and consequently, meat tenderness and growth rate (Aali et al., 2014).

Another possible marker for meat quality and growth characteristics is the myostatin gene (GDF-8). This gene acts as a negative regulator of muscle growth, in which gene mutations are responsible for the double musculature phenotype in several cattle breeds (Crisà et al., 2003). Myostatin is expressed in the pre- and postnatal, skeletal muscle avoiding excessive differentiation of myoblasts during muscle development. Mutations leading to loss of myostatin function can produce many muscle fibers, resulting in muscle hyperplasia, known as "double-muscling". (Guimarães et al., 2007; Azari et al., 2012). The carcasses of these animals are considered superior, resulting in greater production of soft, lean meats, and noble cuts (Teixeira et al., 2006).

Therefore, the objective of the present study was to evaluate single nucleotide polymorphisms (SNPs) in the CAST gene and in the promoter region of the GDF-8 gene and to associate them with meat physicochemical characteristics of Santa Inês Sheep and Santa Inês crossed with five different breeds (Black Dorper, White Dorper, Texel, Lacaune and East Friesian).

\section{MATERIAL AND METHODS}

This study was approved by the Committee on Ethics in Animal Use CEUA/UFLA registered under number 102/12. The maintenance of the animals and slaughter were carried out in the Sheep Production sector, the quality analyses were done in the Laboratory of Meat and Fish Technology of the Department of Food Science, and the analyses of the genes under study were carried out in the Central Laboratory of Molecular Biology at the Federal University of Lavras, located in Lavras, Minas Gerais, Brazil.

\section{Animals}

The study was carried out with 84 lambs represented by purebred animals - Santa Inês -SI $(n=14)$ and 70 crossbreds, from Santa Inês crosses and five different rams, being: 16 animals ( $1 / 2$ Santa Inês x $1 / 2$ Black Dorper - BD); 12 animals ( $1 / 2$ Santa Agnes x 1/2 White Dorper - WD); 19 animals ( $1 / 2$ Santa Inês x $1 / 2$ Texel - TX); 14 animals ( $1 / 2$ Santa Inês X 1/2 Lacaune - LCI) and 9 animals ( $1 / 2$ Santa Inês x $1 / 2$ East Friesan - EF).

All the animals were kept in the same sector of Sheep Production at the Federal University of Lavras (UFLA) under the same housing and feeding conditions. The experimental period began when lambs weighed, on average $24.19 \pm 2.46 \mathrm{~kg}$ and were 3 months of age. The lambs were fed diets containing $80 \%$ concentrate and $20 \%$ roughage, based on oat hay, coffee husk, soybean meal, corn, limestone, mineral supplement, Rumensin ${ }^{\circledR}$, and bypass fat (Megalac) at $5.3 \%$ of the diet. The sheep were slaughtered with a live weight of $43.99 \pm 1.21 \mathrm{~kg}$, under appropriate conditions of slaughter, according to IN 03 of 1/07/2000 of the Ministry of Livestock and Supply - MAPA (Brasil, 2000), and before slaughter, the animals were submitted to a rest period of 24 hours, fasting and water diet. 
All procedures described were approved by the Ethics Committee on Animal Use (CEUA) of the Federal University of Lavras (protocol number 102/12).

\section{Genotyping}

The blood samples $(5 \mathrm{~mL})$ were collected from 84 sheep and packed in EDTAcoated tubes, and stored at $-80^{\circ} \mathrm{C}$. The genomic DNA was extracted according to the protocol of Regitano (2001). The concentration and purity of the extracted DNA were quantified by using absorbance at 260nm (A260) and 280nm (A280) in a Nanodrop 1000 spectrophotometer (ThermoFischer Scientific, Waltham, MA, USA), and its integrity observed on agarose gel (0.8\%). The samples were diluted with UltraPure DNase/RNaseFree Distilled Water (ThermoFischer Scientific, Waltham, MA, USA) to give the desired final concentration of $10 \mu \mathrm{g} \mathrm{DNA} / \mu \mathrm{L}$.

\section{DNA Amplification}

Genomic DNA amplification was through the Polymerase Chain Reaction (PCR). Two kits of primers were checked: for CAST gene $(622 \mathrm{pb})$ : forward (1C 5'TGGGGCCCAATGACGCCATCGATG-3') and reverse (1D 5'GGTGGAGCAGCACTTCTGATCACC -3') according to Palmer et al. (1998) and for the GDF-8 gene promoter region (561pb): forward (5' CTGAGGGAAAAGCATATCAAC 3') and the reverse (5' -CCAGCAACAATCAGCATAAATAG -3') according to Crisà et al. (2003).

PCR was performed from $50 \mathrm{ng}$ of genomic DNA in a final volume of $25 \mu \mathrm{l}$ containing $1 \times$ reaction buffer; $200 \mu \mathrm{M}$ of dNTP; $1.25 \mathrm{U}$ Taq DNA polymerase (Promega); $2.5 \mathrm{mM}$ of $\mathrm{MgCl}_{2}$ and $0.5 \mu \mathrm{M}$ of each primer and $\mathrm{H}_{2} \mathrm{O}$. PCR reactions were performed by a thermocycler (Mastercycler - Eppendorf) with the following thermal cycling profile: initial denaturation at $95^{\circ} \mathrm{C}$ for $5 \mathrm{~min}$, followed by 35 cycles of $95^{\circ} \mathrm{C}$ for $30 \mathrm{sec} ; 61^{\circ} \mathrm{C}$ and $60^{\circ} \mathrm{C}$ respectively for the CAST gene, and for the promoter region of the GDF-8 gene, each gene quoted for $30 \mathrm{~s}$ and $72^{\circ} \mathrm{C}$ for $30 \mathrm{~s}$. The final prolongation was of 2 min at $72^{\circ} \mathrm{C}$. The PCR products were visualized by $0.8 \%$ agarose gel electrophoresis by using TAE buffer and $1 \times$ staining with $200 \mathrm{ng} / \mathrm{mL}$ ethidium bromide.

For the carrying out of the Simple Chain Conformation polymorphism (PCR-SSCP) technique, for each $1 \mu \mathrm{L}$ PCR product were added $10 \mu \mathrm{L}$ of denaturing buffer $(98 \%$ formamide, $20 \mathrm{mM}$ EDTA, $0.05 \%$ bromophenol blue, and $0.05 \%$ xylenecianol). After denaturation at $95^{\circ} \mathrm{C}$ for $5 \mathrm{~min}$, the samples were immediately placed on ice and then applied onto the $12.5 \%$ acrylamide: bisacrylamide (37.5: 1) gel. Electrophoresis was performed in a vertical vessel (Hoefer TM Minive) at $10^{\circ} \mathrm{C}$ in $0.5 \times \mathrm{TBE}$ buffer for $48 \mathrm{~h}$ and $6 \mathrm{~h}$, respectively for CAST and GDF-8 at $300 \mathrm{~V}$ in a $10^{\circ} \mathrm{C}$ environment. The gels were stained with silver nitrate according to the protocol described by Byun (2009).

\section{Sequencing and data analysis}

The samples obtained from the PCR-SSCP analysis according to each standard presented on the gels were sequenced by capillary electrophoresis in ABI3130 apparatus by using POP7 polymer and BigDye Terminator v3.1, Cycle Sequencing Kit (Applied Biosystems, Madrid, Spain). 
After sequencing, the quality of the spherograms and the nucleotide sequences generated by the free software Sequence Scanner Software (Applied Biosystems ${ }^{\circledR}$ ) was checked. The reads were aligned against ovine genomes (Ovis aries) deposited in the NCBI (National Center for Biotechnology Information), and JustBio's computational tools (www.justbio.com), respectively. Searches for homologous and sequence alignment were performed with BLAST (https://blast.ncbi.nlm.nih.gov/Blast.cgi) and the program ClustalW2 (http://www.ebi.ac.uk/Tools/msa/clustalw2/). Mutations that appeared in more than two animals as compared to the reference genome were regarded as polymorphisms.

\section{Analysis of meat quality}

The meat quality parameters evaluated were: $\mathrm{pH}$, color, weight loss per cooking (WLC), shear force (SF), myofibillary fragmentation index (MFI), collagen content (TCC), and sarcomere length (SL). The $\mathrm{pH}$ was measured by using a DIGIMED DM-20 potentiometer coupled to an electrode at $24 \mathrm{~h}$ post mortem, and after the maturation period of 10 days at $2^{\circ} \mathrm{C}$ in the Longisssimus lumborum muscle according to the methodology of Zapata et al. (2000). Meat color parameters were performed on the muscle cut surface by using the colorimeter apparatus (Konica Minolta CM-700, Singapore). It operated the CIELAB system, with D65/10 illuminant, to obtain the luminance indices ( $\left.\mathrm{L}^{*}\right)$, redness (a $*)$, yellowness $\left(\mathrm{b}^{*}\right)$, saturation index - Chroma $\left(\mathrm{C}^{*}\right)$ and hue angle $(\mathrm{h} *)$. The weight loss by cooking was determined after the cooking of the samples. Shear force (SF) was determined by using a TA-XT2 texturometer (Texture Technologies Corp./Stable Micro Systems). The myofibrillar fragmentation index was quantified according to the methodology of Culler et al. (1978). Collagen, fractions and sarcomere were determined by methods of Wheeler et al. (2002).

\section{Statistical analyses}

The genotypic and allele frequencies were performed by direct counting. The data were analyzed through the GLM procedure of SAS (Statistical Analysis System, 2011 SAS 9.3 Inst. Inc., Cary, NC). Means were compared using Tukey Test $(\alpha=0.05)$ for the effect of the breed groups and genotypes of each gene.

\section{RESULTS AND DISCUSSION}

\section{PCR-SSCP and analysis of the $C A S T$ and GDF-8 genes}

In this study, the two genes (CAST and the promoter region of the GDF-8 gene) of the six sheep breed groups presented a unique band in the PCR products, being used directly for the analysis of PCR-SSCP. The results of this analysis revealed the presence of four genotypes (AA, AB, BB and $\mathrm{BC}$ ) and three alleles (A, B and C) for the CAST gene, and in the promoter region of the GDF-8 gene, three different genotypes, (DD, DE, DF) and three alleles (D, E and F) (Figure 1).

Using the same pair of primers for the CAST gene; Ranjbari et al. (2012) found similar results, four genotypes (AA, BB, $\mathrm{AB}$ and $\mathrm{AC}$ ) and three alleles $(\mathrm{A}, \mathrm{B}$ and $\mathrm{C})$ in sheep of the Makoei breed by the PCR-SSCP technique. Likewise, three genotypes (MM, 
$\mathrm{MN}$ and $\mathrm{NN}$ ) were found in sheep of the Dalagh breed through the Restriction Fragment Length Polymorphism (RFLP) technique by Azari et al. (2012). Using the PCR-SSCP technique, Aali et al. (2012) also found the existence of eight different patterns for the CAST gene in 487 sheep of four ancient sheep breeds in Iran. For the GDF-8 gene, in a study conducted in China evaluating 364 sheep of breeds specialized in meat, milk and wool and using the PCR-SSCP technique, Gan et al. (2008) identified two genotypes in the promoter region.

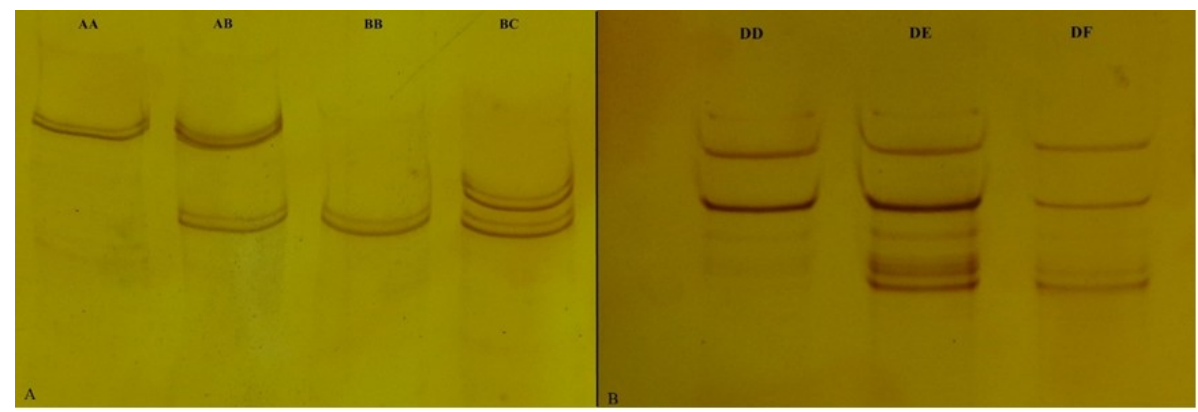

Figure 1. 12.5\% polyacrylamide gel using the PCR-SSCP technique, identifying: (A) four different genotypes (AA, AB, BB and BC) with three different alleles (A, B, C) of SNPs in the CAST gene; (B) three different genotypes (DD, DE, DF) with three different alleles (D, E, F) of SNPs in the promoter region of the GDF-8 gene in sheep.

In this study, the sheep population presented a good degree of genotypic variability for the CAST and GDF-8 genes. According to the analyses conducted in the genotype frequencies of the CAST gene for the different breed groups, it was found that the BB genotype was predominant. The $\mathrm{AA}$ and $\mathrm{AB}$ genotypes presented higher occurrence in $\mathrm{LC}$ animals ( $1 / 2$ Santa Inês X $1 / 2$ Lacaune). The SI (Santa Inês) and TX ( $1 \frac{1}{2}$ Santa Inês X $1 / 2$ Texel) animals showed higher frequencies for BB genotype; while the $\mathrm{BC}$ genotype was only found at the EF crossing ( $1 / 2$ Santa Inês $x 1 / 2$ East Friesan) (Table 1). Allele frequencies for the CAST gene are shown in Table 1 for the A, B and C alleles.

Table 1. Frequency of Polymorphism genotypes (SNP) according to the Simple Chain Conformation Polymorphism (PCR-SSCP) technique of the Calpastatin gene (CAST), of the promoter region of the myostatin gene (GDF-8) in each breed group of sheep.

\begin{tabular}{|c|c|c|c|c|c|c|c|c|c|c|}
\hline \multirow{2}{*}{ Gene } & \multirow{2}{*}{ Genotype } & \multicolumn{6}{|c|}{ Breed Group } & \multirow{2}{*}{ Overall } & \multirow{2}{*}{ Allele } & \multirow{2}{*}{ Overall } \\
\hline & & LC & SI & EF & BD & WD & TX & & & \\
\hline \multirow{4}{*}{ CAST } & AA & 0.214 & 0.143 & 0.000 & 0.000 & 0.083 & 0.000 & 0.714 & $\mathrm{~A}$ & 0.173 \\
\hline & $\mathrm{AB}$ & 0.357 & 0.00 & 0.111 & 0.313 & 0.333 & 0.105 & 0.202 & B & 0.821 \\
\hline & $\mathrm{BB}$ & 0.429 & 0.857 & 0.778 & 0.688 & 0.583 & 0.895 & 0.714 & $\mathrm{C}$ & 0.006 \\
\hline & $\mathrm{BC}$ & 0.000 & 0.000 & 0.111 & 0.000 & 0.000 & 0.000 & 0.119 & - & - \\
\hline \multirow{3}{*}{ GDF-8 } & DD & 0.143 & 0.000 & 0.111 & 0.062 & 0.167 & 0.105 & 0.953 & $\mathrm{D}$ & 0.547 \\
\hline & DE & 0.786 & 0.857 & 0.778 & 0.750 & 0.667 & 0.632 & 0.738 & $\mathrm{E}$ & 0.369 \\
\hline & DF & 0.071 & 0.143 & 0.111 & 0.188 & 0.167 & 0.263 & 0.167 & $\mathrm{~F}$ & 0.084 \\
\hline
\end{tabular}

LC - Lacaune x Santa Inês; SI - Santa Inês puro; EF - East Friesian x Santa Inês; BD - Black Dorper x Santa Inês; WD - White Dorper x Santa Inês; TX - Texel x Santa Inês. 
Results of variations in the genotypic frequency for the CAST gene were also reported by Azari et al. (2012), who found genotype frequencies of 0.36 for MM, 0.38 for $\mathrm{MN}$, and 0.26 for NN in a population of 110 Dalagh sheep in Iran. Whereas, in a population of 100 Makoei sheep, the genotypic frequency in the CAST gene was 0.31 for AA; 0.04 for $\mathrm{BB} ; 0.63$ for $\mathrm{AB}$, and 0.02 for $\mathrm{AC}$ (Ranjbari et al., 2012).

The allele frequencies for the CAST gene in this study are similar to those reported by Ranjbari et al. (2012). They observed allele frequencies of $0.6313,0.3586$ and 0.0100 for the $\mathrm{A}, \mathrm{B}$ and $\mathrm{C}$ alleles, respectively in their study, analyzing Makoei sheep applying the PCR-SSCP technique. This concurs with our results, since A and B alleles were more frequent. However, Azari et al. (2012) verified the presence in Dalagh sheep, by RFLP, of only two alleles (M and $\mathrm{N}$ ) that presented a frequency of 0.5545 and 0.4455 , respectively.

For the GDF-8 gene, the DE genotype presented higher prevalence in the groups studied, with higher occurrence for SI animals, whereas TX animals showed higher frequency of the DF genotype (Table 1). Allele frequencies for the D, E and $\mathrm{F}$ alleles of the GDF-8 gene are presented in Table 1. Genotypic and allele frequencies for this gene were also reported for 30 Merino Dzhalginsky sheep, with respective values of $0.90,0.05$ and 0.05 for AA, AG and GG genotypes, and of 0.925 and 0.075 for the A and $\mathrm{G}$ alleles (Trukhachev et al., 2015). Thus, it is possible to infer that the CAST and GDF-8 genes are polymorphic in the ovine population, regardless of origin, genetic groups and techniques used to detect these mutations (Azari et al., 2012).

\section{Data sequencing}

The data obtained in the sequencing of each genotype of the CAST gene revealed the presence of five base-change polymorphisms (A/G; G/A and T/C) (Figure 2).

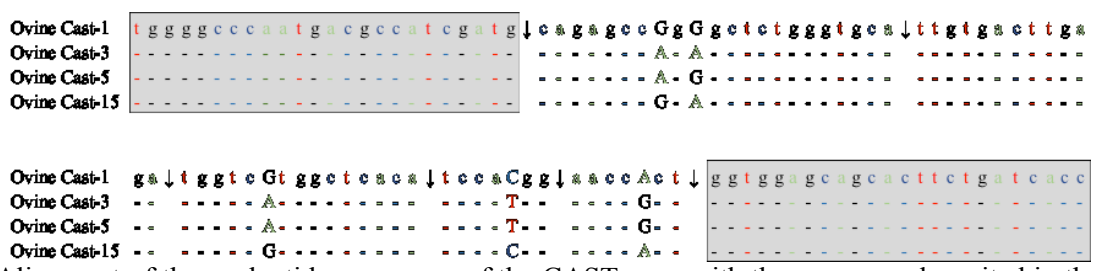

Figure 2. Alignment of the nucleotide sequences of the CAST gene with the sequence deposited in the GenBank accession number AF016007, using tools from the JustBio site (2019) of the sheep. The nucleotides in exon 1 are indicated with lowercase letters. SNPs are represented by uppercase letters. The arrows indicate sequenced regions that did not show SNPs and were removed for better visualization of the image. The shaded regions indicate the binding regions of the primers. Hyphens indicate equality. Ovine Cast-1 (GenBank reference sequence: AF016007), and Ovine Cast-3, 5 and 15 (sequences evaluated in the present study).

From the five SNPs detected in the sequencing of the CAST gene, two polymorphisms (c.227A> G; c.383G>A), resulted in the exchange of the amino acid glutamic acid by glycine, and the amino acid threonine by alanine, respectively (Figure 3).

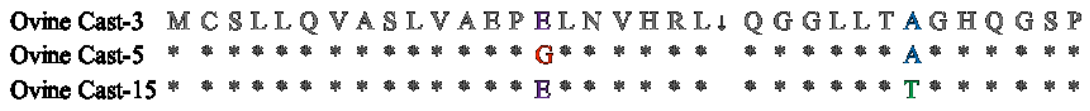

Figure 3. Alignment of amino acids from CAST gene to sheep samples using Clustal W2. The capital letters are the amino acids. Stars $(*)$ mean that they are the same. Arrows indicate sequenced regions that did not show SNPs and were removed for better imaging. Ovine Cast-3, 5 and 15 are the sequences evaluated in the present study. 
Aali et al. (2014) identified four SNPs in intron 5 and three SNPs in exon 6 of the CAST gene, (c.197A > T, c.282G > T e c.296C > G), the latter of which resulted in the substitutions p.Gln Leu, p.Glu $>$ Asp and p.Pro $>$ Arg, respectively. All of these amino acid substitutions were responsible for changes in the physicochemical and activity properties of the $\mathrm{Ca}^{2+}$ channels and had an effect on the meat tenderness of the animals studied by Aalli et al (2014).

Esteves et al. (2019) conducted a study to evaluate the occurrence of polymorphisms in the Diacilglycerol Acyltransferase (DGTA 2) gene that may be related to the lipid profile, 84 sheep from different genetic groups were tested, using the PCR- SSCP. Four genotypes were found with the presence of 6 polymorphisms, two (c.229T> C; c. $255 \mathrm{~T}>\mathrm{C}$ ) that resulted in the exchange of phenylalanine for leucine.

In the literature there are no reports of the change in (c.227A> G; c. $383 \mathrm{G}>\mathrm{A})$ that resulted in the amino acid exchange in the calpastatin gene and, consequently, its relationship with meat tenderness.

In the present study, the change of $c .227 \mathrm{~A}>\mathrm{G}$ in the patterns of bands $\mathrm{AA}, \mathrm{AB}$ and $\mathrm{BB}$, and the change of $\mathrm{c} .383 \mathrm{G}>\mathrm{A}$, in the standards $\mathrm{AA}$ and $\mathrm{AB}$ was checked. These patterns were most observed in the breed groups WD ( $1 / 2$ Santa Inês $x 1 / 2$ White Dorper) and LC ( $1 / 2$ Santa Inês x $1 / 2$ Lacaune), which presented values of meat tenderness close to $4.5 \mathrm{kgf}$ (table 2).

For the GDF-8 gene promoter region, the presence of three base-change polymorphisms (A / T), (A / G) and (T/G) was investigated (Figure 4).

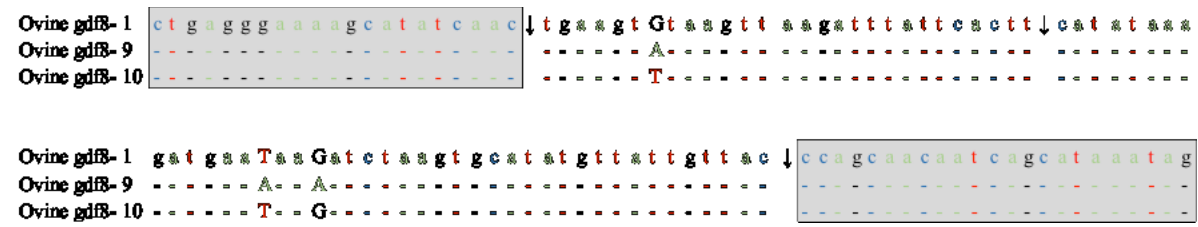

Figure 4. Alignment of the nucleotide sequences of the promoter region of the GDF-8 gene of sheep using JustBio (2019) website tools with the sequence deposited in GenBank accession number DQ530260.1. The nucleotides in the promoter region are indicated with lowercase letters. SNPs are represented by uppercase letters. The arrows indicate sequenced regions that did not show SNPs and were removed for better visualization of the image. The shaded regions indicate the binding regions of the primers. The traces indicate equality. Ovine GDF81 (GenBank reference sequence: DQ530260.) and Ovine GDF8 -9 and 10 (sequences evaluated in our study).

Corroborating our results, a study carried out in China evaluating 364 sheep of breeds specialized in meat, milk and wool, using the PCR-SSCP technique found four SNPs in the GDF-8 promoter region (Gan et al., 2008).

Regarding the SNPs found in the promoter region of the GDF-8 gene, in our study, these did not result in amino acid change, and consequently there was no protein change. Nevertheless, there are reports of a $\mathrm{G} \rightarrow \mathrm{T}$ base change in the GDF-8 gene in Marchigiana cattle, which is involved in the inactivation of myostatin and double musculature (Marchitelli et al., 2003). Finally, the DE pattern was the one that presented the most SNP's and was in a higher percentage $(0.857 \%)$ of occurrence in the SI genetic group, which presented greatest tenderness (3.64 kgf), as can be seen in Table 2 . 


\section{Meat quality analysis}

The evaluation of the quality parameters revealed effects of the breed groups $(\mathrm{P}=$ 0.004) on the values of Shear Force (SF) in the Longissimus lumborum muscle at $24 \mathrm{~h}$; while it was found relationship of the CAST genes upon the values of final $\mathrm{pH}(0.004)$, and of the GDF-8 gene, hue angle $(\mathrm{h} *)(\mathrm{P}=0.006)$ for this muscle after maturation for 10 days at $2^{\circ} \mathrm{C}$ (Table 2$)$.

Table 2. Means, significance and slicing of the physicochemical parameters of meat for the different breed groups of sheep and genotypes of the CAST and GDF-8 genes.

\begin{tabular}{|c|c|c|c|c|c|c|c|c|c|c|c|}
\hline \multirow{3}{*}{ Variables } & & \multicolumn{5}{|c|}{ Fresh (24h post mortem) } & \multicolumn{5}{|c|}{ Ageing $\left(10\right.$ days at $\left.2^{\circ} \mathrm{C}\right)$} \\
\hline & & \multirow{2}{*}{ Mean } & \multirow{2}{*}{ SEM } & \multicolumn{3}{|c|}{ P Value* } & \multirow{2}{*}{ Mean } & \multirow{2}{*}{ SEM } & \multicolumn{3}{|c|}{ P Value* } \\
\hline & & & & GEN & CAST & GDF & & & GEN & CAST & GDF \\
\hline SF (kgf) & & 4.70 & 1.53 & 0.004 & 0.414 & 0.725 & 3.23 & 1.10 & 0.174 & 0.840 & 0.950 \\
\hline $\mathrm{pH} 24 \mathrm{~h}$ & & 5.70 & 0.11 & 0.446 & 0.067 & 0.341 & 5.70 & 0.11 & 0.215 & 0.004 & 0.181 \\
\hline WLC (\%) & & 23.60 & 4.26 & 0.381 & 0.285 & 0.534 & 23.29 & 3.62 & 0.318 & 0.129 & 0.895 \\
\hline $\mathrm{SL}(\mu \mathrm{m})$ & & 1.40 & 0.14 & 0.724 & 0.790 & 0.649 & 1.44 & 0.20 & 0.375 & 0.583 & 0.147 \\
\hline $\mathrm{L}^{*}$ & & 48.10 & 2.88 & 0.232 & 0.989 & 0.320 & 48.88 & 3.50 & 0.487 & 0.629 & 0.185 \\
\hline $\mathrm{a}^{*}$ & & 6.00 & 1.85 & 0.565 & 0.697 & 0.876 & 5.77 & 2.16 & 0.650 & 0.995 & 0.498 \\
\hline $\mathrm{b}^{*}$ & & 8.20 & 1.44 & 0.723 & 0.941 & 0.633 & 8.72 & 1.76 & 0.293 & 0.383 & 0.562 \\
\hline $\mathrm{C}^{*}$ & & 10.2 & 2.22 & 0.651 & 0.851 & 0.846 & 10.50 & 2.60 & 0.502 & 0.745 & 0.748 \\
\hline $\mathrm{h}^{*}$ & & 54.2 & 3.75 & 0.415 & 0.268 & 0.148 & 57.13 & 4.86 & 0.244 & 0.124 & 0.006 \\
\hline MFI (\%) & & 33.3 & 8.51 & 0.966 & 0.951 & 0.597 & 52.26 & 14.7 & 0.313 & 0.274 & 0.468 \\
\hline $\mathrm{SCC}$ & & 0.6 & 0.17 & 0.254 & 0.943 & 0.395 & 0.60 & 0.17 & 0.483 & 0.287 & 0.985 \\
\hline ICC & & 1.6 & 0.40 & 0.303 & 0.181 & 0.295 & 1.56 & 0.36 & 0.233 & 0.155 & 0.801 \\
\hline TCC & & 2.2 & 0.51 & 0.501 & 0.277 & 0.259 & 2.16 & 0.49 & 0.267 & 0.156 & 0.876 \\
\hline \multicolumn{12}{|c|}{ Statistical Breakdown* } \\
\hline \multirow{2}{*}{ GEN } & \multirow{2}{*}{\multicolumn{2}{|c|}{ SF }} & $\mathrm{BD}$ & $\mathrm{EF}$ & $\mathrm{LC}$ & SI & $\mathrm{TX}$ & & WD & \multirow{2}{*}{\multicolumn{2}{|c|}{$\begin{array}{l}\text { EPM } \\
0.529\end{array}$}} \\
\hline & & & $5.58 \mathrm{ab}$ & $3.74 \mathrm{bc}$ & $4.38 \mathrm{abc}$ & $3.64 \mathrm{c}$ & $5.91 \mathrm{a}$ & & $4.67 \mathrm{abc}$ & & \\
\hline \multirow{2}{*}{ CAST } & \multirow{2}{*}{\multicolumn{2}{|c|}{$\mathrm{pH} 24 \mathrm{~h}$}} & AA & & $\mathrm{AB}$ & & BB & & & \multirow{2}{*}{\multicolumn{2}{|c|}{0.049}} \\
\hline & & & $5.86 \mathrm{a}$ & & $5.67 \mathrm{~b}$ & & $5.68 \mathrm{~b}$ & & & & \\
\hline \multirow{2}{*}{ GDF } & \multirow{2}{*}{$\mathrm{h}^{*}$} & & DD & & $\mathrm{DE}$ & & $\mathrm{DF}$ & & & \multirow{2}{*}{\multicolumn{2}{|c|}{2.237}} \\
\hline & & & $50.78 \mathrm{~b}$ & & $58.10 \mathrm{a}$ & & $55.08 \mathrm{ab}$ & & & & \\
\hline
\end{tabular}

*Tukey Test $(\alpha=0,05)$; GEN $=$ effect of the breed group, CAST $=$ effect of genotype on the CAST gene; GDF $-8=$ effect of genotype on GDF-8 gene; SF = Shear force; WLC = Weight Loss per Cooking; $\mathrm{L} *=$ Brightness; $\mathrm{a} *=$ Redness; $\mathrm{b} *=$ Yellowness; $\mathrm{c} *$ - Saturation index - chroma; $\mathrm{h} *=$ Hue angle of the color; $\mathrm{SL}=$ sarcomere length; MFI = myofibrillar fragmentation index; TCC $=$ Total collagen content; ICC - Insoluble collagen content (mg/g collagen); SCC = Soluble collagen content; SEM = Standard error of the mean; LC Lacaune x Santa Inês; SI - Santa Ines pure; EF - East Friesian x Santa Inês; BD - Black Dorper x Santa Inês; WD - White Dorper x Santa Inês; TX - Texel x Santa Inês.

The highest values of SF were found in the Longissimus lumborum muscles at $24 \mathrm{~h}$ post-mortem in the TX ( $1 / 2$ Santa Inês x $1 / 2$ Texel) and the lowest ones for the SI (purebred Santa Inês) animals, indicating greater tenderness for the meat of this group, not being found any statistically significant difference among the breed groups after the maturation period $(\mathrm{P}=0.174)$. In the literature, the values of SF range between $4.63 \mathrm{kgf}$ to $13.57 \mathrm{kgf}$ for meat of several sheep crosses (Zapata, et al., 2000; Souza et al., 2004). According to Alves \& Marcio (2007), the shear force value of less than $4.5 \mathrm{kgf}$ is the force of a meat with acceptable tenderness in cattle. Therefore, it can be inferred that breed groups LC, EF and SI have tender meat.

The different genotypes of the CAST gene showed a difference in relation to the final $\mathrm{pH}$ value after the maturation period, with highest mean for the animals with the AA genotype, and lowest for the $\mathrm{AB}$ and $\mathrm{BB}$ genotypes (Table 2). In the literature, the importance of initial and final $\mathrm{pH}$ on meat tenderness during the maturation period is evidenced, as the enzymes involved (calpain and calpastatin) are calcium and $\mathrm{pH}$-dependent (Hopkins \& Taylor, 2004; Veiseth et al., 2001). During the gradual decline of muscle tissue 
$\mathrm{pH}$ at post mortem, release of calcium ions from the sarcoplasmic reticulum occurs with the activation of m-calpain (Koohmaraie, 1994; Du Toit and Oguttu, 2013). This acts on the tenderization and maturation process of the meat. In these studies, it was only possible to check the difference in tenderness in the first 24 hours after slaughter, despite no differences in $\mathrm{pH}$ value were observed. However, at the end of the maturation period (10 days), there were differences in $\mathrm{pH}$ values: reduction of $\mathrm{pH}$ at $\mathrm{BB}$ and $\mathrm{AB}$ genotypes, and increased $\mathrm{pH}$ at AA genotype. While SF values were similar, this may indicate distinct expression of calpastatin (CAST) due to the polymorphism and frequency of the genes in the groups evaluated.

Regarding hue angle $\left(\mathrm{h}^{*}\right)$, this was affected by the genotypes of the GDF-8 gene after the maturation period, with highest values for the DE genotype (Table 2). The hue angle $(\mathrm{h} *)$ represents the actual color of the meat, being determined according to the values of $\mathrm{a}^{*}$ and $\mathrm{b}^{*}$ and associated with the meat discoloration process (Bosco et al., 2016). Thus, for possessing the greatest occurrence of the DE genotype, the SI gene group may present a lighter coloration, because in the DE genotype, the $\mathrm{G} \rightarrow \mathrm{T}$ base exchange occurred in the promoter region. This could result in the reduction of the activation of the myostatin. Animals with less myostatin activity have paler meat, being the result of myoglobin concentration, which changes according to the distribution of metabolic fiber types; i.e., a greater presence of white fibers, a lesser amount of myoglobin in the muscles of these animals (Boccard, 1982).

\section{CONCLUSIONS}

We found that the CAST genes and the GDF-8 promoter region variy in sheep, and some SNPs can alter the meat quality parameters in this species. Scanning for polymorphisms revealed in the CAST gene two SNPs (c.679A> G; c.383A> G), which resulted in the exchange of glutamic acid for glycine and threonine for alanine. In the DGF8 gene there were three SNPs $\mathrm{A}>\mathrm{T}, \mathrm{A}>\mathrm{G}$ and $\mathrm{T}>\mathrm{G}$, without amino acid alteration. These results revealed a significant association with $\mathrm{pH}$ and hue angle $\left(\mathrm{h}^{*}\right)$ values, respectively. These results couldcontribute to future research with molecular markers, in addition to confirming that the PCR-SSCP technique is an adequate tool to evaluate genetic variability.

\section{ACKNOWLEGDMENTS}

The authors are grateful to FAPEMIG (Foundation for Research Support of the State of Minas Gerais), which made it possible to carry out this study through financial assistance.

\section{CONFLICTS OF INTEREST}

The authors declare no conflict of interest.

\section{REFERENCES}

Aali M, Moradi-Shahrbabak M, Moradi-Shahrbabak H and Sadeghi M (2014). Detecting novel SNPs and breed-specific haplotypes at calpastatin gene in Iranian fat- and thin-tailed sheep breeds and their effects on protein structure. Gene. 537: 132-139. 
Adeyemi KD and Sazili AQ (2014). Efficacy of Carcass Electrical Stimulation in Meat Quality Enhancement: A Review. Asian Australas J. Anim Sci. 27: 447-468.

Allais S, Levéziel H, Payet-Duprat N, Hocquette JF, et al. (2010). The two mutations, Q204X and nt821, of the myostatin gene affect carcass and meat quality in young heterozygous bulls of French beef breeds. J. Anim. Sci. 88: 446-454.

Alves DD and Mancio AB (2007). Maciez da carne bovina: uma revisão. Rev FZVA. 14: 193-216.

Amaral RM, Macedo FAF, Macedo FG, Lino DA, et al. (2011). Deposição tecidual em cordeiros Santa Inês, 1/2 DorperSanta Inês e 1/2 White Dorper-Santa Inês avaliados por ultrassonografia. Rev. Bras. Saúde Prod. Anim. 12: 658-669.

Ávila VS, Fruet APB, Barbieri M, Bianchini HN, et al. (2013). O retorno da ovinocultura ao cenário produtivo do Rio Grande do Sul. Rev. Elet. em Gestão, Educação e Tecnologia Ambiental. 11: 2419-2426.

Azari MA, Dehnavi E, Yousefi E and Shahmohamadi L (2012). Polymorphism of calpastatin, calpain and myostatin genes in native dalagh sheep in Iran. Slovak J. Anim. Sci. 45: 1-6.

Bailey AJ, Enser MB, Dransfield E, Restall DJ and Avery NC (1982). Muscle and adipose tissue from normal and double muscled cattle. Curr. Top. Vet. Med. Anim. Sci. 16: 178.

Boccard R (1982) Relationship between muscle hypertrophy and the composition of skeletal muscle. Curr. Top. Vet. Med. Anim. Sci. 16: 148 .

Bosco DMS, Andrighetto C, Luz PAC, Poi Atti ML, et al. (2016). Qualidade da carne bovina maturada e tenderizada comercializada na região de Dracena, SP. Bol. Ind. Amin. 73: 304-309.

BRASIL. Ministério da Agricultura. Instrução Normativa $\mathrm{n}^{\circ} 3$, de 07 de janeiro de 2000. Regulamento técnico de métodos de insensibilização para o abate humanitário de animais de açougue. Diário Oficial [da] República Federativa do Brasil, Brasília, 24 jan. 2000. p. 14-16. Available at: $<$ http://www.agricultura.gov.br/das/dipoa/Anexo\%20Abate.htm>. Accessed: 09 nov. 2019.

Byun SO, Fang Q, Zhou H and Hickford JG (2009). An effective method for silver-staining DNA in large numbers of polyacrylamide gels. Anal Biochem. 385: 174-175.

Calvo JH, Iguácel LP, Kirinus JK, Serrano M, et al. (2014). A new single nucleotide polymorphism in the calpastatin (CAST) gene associated with beef tenderness. Meat Sci. 96: 775-782.

Corradello EFA (1988). Criação de ovinos: antiga e contínua atividade lucrativa. São Paulo: Ícone, 124.

Crisá A, Marchitelli C, Savarese MC and Valentini A (2003) Sequence analysis of myostatin promoter in cattle. Cytogenet. Genome Res. 102: 48-52.

Culler RD, Parrish JRFC, Smith GC and Cross HR (1978). Relationship of myofibril fragmentation index to certain chemical physical and sensory characteristics of bovine longissimus muscle. J. Food Sci. 43: 1177.

Della Torre J C M and Beraquet N J (2005). Composição centesimal e teor de colágeno em carne bovina moída. Rev. Inst. Adolfo Lutz. 64: 223-231.

Du Toit E and Oguttu JW (2013). Calpain and Calpastatin activity post mortem and meat tenderness: are the two related? J. Anim. Vet. Advances. 12: 683-688.

Esteves C, Livramento KG, Paiva LV, Peconick AP, et al. (2019). The polymorphisms of genes associated with the profile of fatty acids of sheep. Arq. Bras Med. Vet. Zootec. 71: 303-313.

Gan S Q, Du Z, Liu S R, Yang Y L, et al. (2008). Association of SNP Haplotypes at the Myostatin Gene with Muscular Hypertrophy in Sheep. Asian-Australas J. Anim. Sci. 21: 928-935.

Guimarães SEF, Stahl CH, Lonergan SM, Geiger B, et al. (2007). Myostatin promoter analysis and expression pattern in pigs. Livestock Sci. 112: 143-150.

Hopkins DL and Taylor RG (2004). Post-mortem muscle proteolysis and meat tenderness. In: Muscle Development of Livestock Animals - Physiology, Genetics and Meat Quality. Cambridge: Cabi Publishing 1: 363-381.

Justbio - Bioinformatics at the tipo f your fingers. Available at: < http://www.justbio.com/hosted-tools.html $>$. Accessed on: Nov 10, 2019.

Koohmaraie M (1994). Muscle Proteinases and Meat Aging. Meat Sci. 36: 93-104.

Kuchtik J, Sustová K, Urban T and Zapletal D (2008). Effect of the stage of lactation on milk composition, its properties and the quality of rennet curdling in East Friesian ewes. Czech J. Anim. Sci. 53: 55-63.

Lira AB, Gonzaga Neto S, Sousa WH, Ramos JPF, et al. (2017). Desempenho e características de carcaça de dois biótipos de ovinos da raça Santa Inês terminados a pasto suplementados com blocos multinutricionais. Rev. Bras. Saúde Prod. Anim. 18: 313-326.

Marchitelli C, Savarese MC, Crisà A and Nardone A (2003). Double muscling in Marchigiana beef breed is caused by a stop codon in the third exon of myostatin gene. Mamm. Gen. 14: 392-395.

Oliveira RV, Ximenes FHB, Mendes CQ and Ferreira Passos RRFC (2011). Manual de criação de caprinos e ovinos. Brasília: Codevasf, 2011. 142 p. Available at: http:// www.codevasf.gov.br/acesso-ainformacao/institucional/bibliotecageraldorocha/publicacoes/arquivos/Manual_Ovinos_e_Caprinos_Verso_Final_rev_jun2011.pdf $>$. Accessed on: 09 Jan. 2020.

Palmer BR, Roberts N, Hickford JG and Bickerstaffe R (1998). Rapid communication: PCR-RFLP for MspI and NcoI in the ovine calpastatin gene. J. Anim. Sci. 76: 1499-1500. 
Ranjbari M, Hashemi A, Mardani K and Darvishzadeh R (2012). Allelic polymorphism of Makoei sheep calpastatin gene identified by polymerase chain reaction and single strand conformation polymorphism. J. Agr. Sci. Tech. 14: 533-538.

Regitano LCA (2001). Extração de DNA para aplicação em reação de cadeia da polimerase. In: Regitano, L.C.A.; Coutinho, L.L. (Ed.). Biologia molecular aplicada à produção animal. Brasília: Embrapa Informação Tecnológica, pp. 179-186.

Souza XR, Bressan MC, Pérez JRO and Faria PB (2004). Efeitos do grupo genético, sexo e peso ao abate sobre as propriedades físico-químicas da carne de cordeiros em crescimento. Ciênc. Tecnol. Aliment. 24: 543-549.

Statistical analysis system. Version 9.3. Cary: SAS Institute, 2011.

Teixiera CS, Andrade de Oliveira DA and Quirino CR (2006). Musculatura dupla: II- Determinação genética. Arch. Latinoam. Prod. Anim. 14: 17-23.

Trukhachev V, Belyaev V, Kvochko A, Kulichenko A, et al. (2015). Myostatin gene (MSTN) polymorphism with a negative effect on meat productivity in Dzhalginsky Merino sheep breed. J. BioSci. Biotechnol. 4: 191-199.

Veiseth E, Shackelford S D, Wheeler T L and Koohmaraie M (2001). Technical note: comparison of myofibril fragmentation index from fresh and frozen pork and lamb longissimus. J. Anim. Sci. 79: 904-906.

Wheeler T L, Shackelford S D and Koohmaraie M (2002). Sampling methodology for relating sarcomere length, collagen concentration, and the extent of postmortem proteolysis to beef and pork longissimus tenderness. J. Anim. Sci. 80: 982-987.

Zapata JF, Seabra LMJ and Nogueira CM (2000). Estudo da qualidade da carne ovina do nordeste brasileiro: propriedades físicas e sensoriais. Ciênc. Tecnol. Aliment. 20: 274-277. 